\title{
Pengaruh Pemberian Tablet Ferrum (Fe) dengan Kadar Hemoglobin pada Ibu Hamil Trimester III
}

\author{
Influence of Giving Ferrum (Fe) Tablet with Hemoglobin Levels \\ in Pregnant $3^{\text {rd }}$ Trimester Mother \\ Liss Dyah Dewi Arini* dan Udi Budi Harsiwi \\ Program Studi D-III Rekam Medik dan Informasi Kesehatan, Fakultas Ilmu Kesehatan, \\ Universitas Duta Bangsa Surakarta \\ Jl. Bhayangkara Tipes Serengan Kota Surakarta 57154, Jawa Tengah, Indonesia \\ *Corresponding author: leeansz_fortune@yahoo.com
}

Received: February 12, 2019; Revise: April 15, 2019; Accepted: May 15, 2019

DOI: https://doi.org/10.31001/biomedika.v12i1.399

\begin{abstract}
ABSTRAK
Anemia mempunyai peranan sebagai penyebab tingginya angka kematian ibu dan bayi. Menurut Riskesdas 2018 prevalensi anemia kehamilan relatif tinggi, yaitu 48,9\%. Dari data tahun 2018, jumlah ibu hamil yang mengalami anemia paling banyak pada usia 15-24 tahun sebesar 84,6\%, usia 25-34 tahun sebesar 33,7\%, usia 35-44 tahun sebesar 33,6\%, dan usia 45-54 tahun sebesar 24\%. Untuk penanggulangannya diberikan tablet besi selama 90 hari. Hasil survei Riskesdas tahun 2018 cakupan pemberian tablet Fe pada ibu hamil di kabupaten Karanganyar sudah mencapai 100\%, tetapi angka kejadian anemia pada ibu hamil masih tinggi. Tujuan penelitian ini adalah untuk mengetahui pengaruh komsumsi tablet zat besi $(\mathrm{Fe})$ terhadap kadar haemoglobin $(\mathrm{Hb})$ pada ibu hamil Di Klinik Kusumahati Jaten. Sampel menggunakan sampel jenuh dan diperoleh sampel sebanyak 30 orang. Pengumpulan data menggunakan wawancara terpimpin pada ibu hamil trimester III dan laporan klinik Kusumahati Jaten tentang pemeriksaan jumlah tablet $\mathrm{Fe}$ yang telah diberikan pada responden serta kadar $\mathrm{Hb}$ yang diperiksa pertama kali sebelum mengkonsumsi tablet Fe. Selain itu dilakukan pengukuran langsung terhadap $\mathrm{Hb}$ ibu dengan alat Easy Touch. Berdasarkan hasil penelitian dapat disimpulkan bahwa ada pengaruh antara asupan zat besi $(\mathrm{Fe})$ dengan peningkatan kadar hemoglobin $(\mathrm{Hb})$ pada ibu hamil di klinik Kusumahati Jaten Tahun 2018. Hasil pengumpulan data menunjukkan pada pemeriksaan tahap pertama nilai $\mathrm{Hb}$ berada pada katagori rendah sebayak 19 responden $(63 \%)$ dan nilai $\mathrm{Hb}$ pada pemeriksaan tahap dua menunjukkan katagori tinggi sebanyak 23 responden (77\%). Dari hasil penelitian ini diharapkan kepada ibu hamil untuk mengkonsumsi tablet zat besi sesuai dengan jumlah yang sudah ditentukan.
\end{abstract}

Kata kunci : anemia; ibu hamil; Ferrum (Fe); hemoglobin

\section{ABSTRACT}

Anemia has a role as a cause of high maternal and infant mortality. According to Riskesdas in 2018 the prevalence of pregnancy anemia is relatively high, which is 48.9\%. From the data in 2018, the highest number of pregnant women who have anemia at the age of 15-24 years is $84.6 \%$, age 2534 years is $33.7 \%$, age 35-44 years is 33.6\%, and age $45-54$ years at $24 \%$. For the treatment, iron tablets are given for 90 days. The results of the 2018 Riskesdas survey the coverage of Fe tablets for pregnant women in Karanganyar district has reached 100\%, but the incidence of anemia in pregnant women is still high. The purpose of this study was to determine the effect of consumption of iron 
tablets $(\mathrm{Fe})$ on hemoglobin $(\mathrm{Hb})$ levels in pregnant women at the Kusumahati Jaten Clinic. The sample used saturated samples and obtained a sample of 30 people. Data collection used guided interviews in third trimester pregnant women and Kusumahati Jaten clinic reports about examining the amount of $\mathrm{Fe}$ tablets given to respondents and $\mathrm{Hb}$ levels that were first examined before consuming Fe tablets. In addition, direct measurements were taken of the mother's Hb with an Easy Touch tool. Based on the results of the research and discussion that has been described, it can be concluded that there is an influence between iron ( $\mathrm{Fe}$ ) intake and the increase in hemoglobin $(\mathrm{Hb})$ levels in pregnant women in the Kusumahati Jaten clinic, Karanganyar in 2018. in the low category as many as 19 respondents (63\%) and the Hb value on the second stage examination showed in the high category as many as 23 respondents (77\%). From the results of this study it is expected that pregnant women consume iron tablets according to the prescribed amount.

Keywords: anemia; pregnant women; Ferrum (Fe); hemoglobin

\section{PENDAHULUAN}

Kesehatan pada ibu hamil adalah indikator kelima dalam Millennium Development Goals (MDG) yang dicanangkan oleh World Health Organization (WHO) belum tercapai karena masih terdapat $37,1 \%$ ibu hamil yang mengalami anemia di Indonesia. Suplementasi zat gizi besi besi dianggap sebagai salah satu cara paling baik untuk mengatasi anemia pada ibu hamil. Di Indonesia suplementasi zat gizi besi diberikan dalam bentuk tablet yang mengandung $60 \mathrm{mg}$ besi dan 0,25 $\mathrm{mg}$ asam folat dan dikonsumsi selama 90 hari (Candra, 2018).

Persentase tertinggi untuk cakupan ibu hamil mendapat 90 tablet $\mathrm{Fe}$ di Provinsi di Indonesia pada tahun 2014 terdapat di Provinsi Bali (95\%), DKI Jakarta (94,8\%), dan Jawa Tengah (92,5\%), sedangkan untuk cakupan terendah terdapat di Provinsi Papua Barat $(38,3 \%)$, Papua $(49,1 \%)$, dan Banten (61,4\%). Persentase di Provinsi Jawa Tengah pada tahun 2014 sebesar 92,5\% dan nilai ini sudah mengalami kenaikan bila dibandingkan dengan pencapaian tahun 2013 (90,74\%), dengan cakupan tertinggi dicapai Kabupaten Banyumas $(98,77 \%)$ dan terendah Kabupaten Rembang (86\%) (Riskesdas, 2018).

Angka Kematian Ibu (AKI) yang dihitung per 100.000 kelahiran di Indonesia masih menunjukkan penurunan yang lambat. Berdasarkan hasil Survei Demografi dan Kesehatan Indonesia (SDKI), pada tahun 1991 AKI mencapai 390 jiwa, tahun 1997 mencapai 334 jiwa, tahun 2003 mencapai 307 jiwa dan pada tahun 2007 AKI mencapai 228 jiwa (Isdiaty dan Titin, 2013). Angka tersebut akan terus diupayakan menurun menjadi 102 jiwa pada tahun 2015 seperti yang tertuang dalam target Millenium Development Goals (MDGs). Sementara itu, kematian ibu di kota Depok mencapai 17 jiwa pada tahun 2008 (Ungsianik dan Fandiar, 2013).

Anemia adalah suatu keadaan dimana kadar hemoglobin ( $\mathrm{Hb})$ di dalam darah jumlahnya kurang dari rata-rata, di mana kadar $\mathrm{Hb}$ yang normal untuk lakilaki berada di angka 13,8 - 17,2 g/dL, sedangkan pada perempuan sekitar 12,1 15,1 g/dL, . Faktor-faktor yang menyebabkan terjadinya anemia gizi besi adalah status gizi yang dipengaruhi oleh 
pola makanan, sosial ekonomi keluarga, lingkungan dan status kesehatan (Wahyuningsih, 2016). Faktor-faktor yang melatarbelakangi tingginya prevalensi anemia gizi besi di negara berkembang adalah keadaan sosial ekonomi rendah meliputi pendidikan orang tua dan penghasilan yang rendah serta kesehatan pribadi di lingkungan yang buruk (Intarti dan Lina, 2017). Meskipun anemia disebabkan oleh berbagai faktor, namun lebih dari $50 \%$ kasus anemia yang terbanyak di seluruh dunia secara langsung disebabkan oleh kurangnya masukan zat gizi besi (Masrizal, 2007).

Zat besi sangat dibutuhkan selama kehamilan, kurangnya zat besi dapat berpengaruh pada kehamilan seperti terjadinya abortus, persalinan prematuritas, hambatan tumbuh kembang janin dalam rahim, mudah terjadi infeksi dan ketuban pecah dini serta dapat juga terjadi bahaya saat persalinan seperti gangguan his, kekuatan mengejan dan kala I dan II akan berlangsung lama (Fanny, et al, 2012).

Pemberian suplementasi zat gizi besi sudah dicanangkan oleh pemerintah sebagai salah satu cara menanggulangi anemia pada ibu hamil (Kartikasari dan Yusnita, 2018), namun pada kenyataannya belum terlihat adanya hasil yang signifikan terhadap suplementasi besi pada ibu hamil yang bisa dilihat dari prevalensi anemia yang masih tinggi pada hasil Riset Kesehatan Dasar (Riskesdas) 2018 yaitu $37,1 \%$ di tingkat nasional 1, 6-10 (Kartikasari dan Yusnita, 2018). Studi terhadap faktor-faktor yang mempengaruhi hasil suplementasi zat gizi besi diharapkan dapat menjadi acuan bagi Klinik, Puskesmas maupun Dinas Kesehatan di Kabupaten Karanganyar dan Indonesia dalam menyusun kebijakan untuk menurunkan angka anemia pada ibu hamil secara keseluruhan.

Hasil penelitian Rizki, et al (2017) menyatakan bahwa terdapat hubungan yang bermakna antara suplementasi tablet Fe dengan kadar Haemoglobin pada ibu hamil trimester III pada usia ibu hamil di angka 20-35 tahun. Penelitian ini bertujuan untuk mengetahui pengaruh Komsumsi Tablet Zat Besi (Fe) Terhadap Kadar Haemoglobin (Hb) Pada Ibu Hamil Di Klinik Kusumahati Jaten, Karanganyar. Kebaharuan dari penelitian ini adalah bahwa peneliti mengambil sampel berupa ibu hamil yang telah memasuki usia kehamilan trimester III di usia 20-45 tahun dengan melihat karakteristik ibu hamil tersebut dari faktor pendidikan dan pekerjaan.

\section{METODE PENELITIAN}

Desain penelitian ini adalah deskriptif korelatif. Penelitian ini bertujuan untuk mengetahui pengaruh asupan tablet besi $(\mathrm{Fe})$ terhadap kadar $\mathrm{Hb}$ ibu hamil di Klinik Kusumahati Jaten, Karanganyar tahun 2018. Penelitian ini bertujuan untuk melihat apakah ada pengaruh pemberian tablet zat besi $(\mathrm{Fe})$ terhadap kadar $\mathrm{Hb}$ ibu hamil pada kelompok responden yang sama. Populasi pada penelitian ini adalah seluruh ibu hamil trimester III di mana usia kehamilannya 24-40 minggu dengan keadaan kehamilan normal di klinik Kusumahati Jaten, Karanganyar sampai 31 Desember 2018 yang berjumlah 30 orang. Sampel dalam penelitian ini berjumlah 30 orang dengan pengambilan sampel berdasarkan sampling jenuh (Notoatmodjo, 
2002) yaitu ibu hamil dengan usia kehamilan di trimester III yang datang ke Klinik Kusumahati Jaten, Karanganyar dan telah diperiksa Hemoglobin $(\mathrm{Hb})$ tahap I serta mengkonsumsi zat besi minimal 60 tablet. Alat pengumpulan data dalam penelitian adalah data demografi responden serta format isian hasil pemeriksaan $\mathrm{Hb}$ tahap pertama dan tahap kedua yang langsung diisi oleh peneliti.

Peneliti menyeleksi responden yaitu ibu hamil dengan usia kehamilan pada trimester III, di mana sudah mengkonsumsi tablet Fe minimal sebanyak 60 butir serta sebelum mengkonsumsi Fe. Pemeriksaan $\mathrm{Hb}$ tahap 1 dan 2 dilakukan di klinik. Sebelum berlangsung penelitian responden mengisi inform consent. Kemudian melakukan wawancara singkat dengan responden tentang identitas ibu hamil dan menanyakan jumlah $\mathrm{Fe}$ yang sudah dikonsumsi. Apabila responden tersebut mengkonsumsi Fe belum sampai 60 butir maka peneliti akan mencari responden yang lain. Apabila responden sesuai dengan kriteria yang telah ditetapkan, selanjutnya dilakukan pemeriksaan $\mathrm{Hb}$ tahap II menggunakan alat Easy Touch. Pengisian dan pengecekan kelengkapan data dan kesesuaian pengisian pada format Setelah pengumpulan data selesai dilakukan, maka selanjutnya memperoleh keterangan telah selesai melakukan pengumpulan data. Pengolahan data dilakukan dengan langkah-langkah editing, coding, transfering dan tabulating. Analisa data dilakukan dengan satu cara, yaitu Univariat yaitu distribusi frekuensi dengan menentukan persentase untuk masingmasing kategori pada tiap-tiap sub variabel penelitian.

\section{HASIL DAN PEMBAHASAN}

Berdasarkan hasil pengumpulan data yang dilakukan selama 10 hari yaitu mulai tangga1 21-31 Desember 2018 di Klinik Kusumahati Jaten, Karanganyar dengan jumlah responden yang terlibat dalam penelitian ini sebanyak 30 responden diperoleh hasil sebagian besar responden berada pada umur 20-30 tahun yang berjumlah 16 orang (53\%), responden yang berada pada umur 30-45 tahun sebanyak 14 orang (47\%). Jika dilihat dari dari pendidikan terakhir maka responden terbanyak berada pada pendidikan menengah (SMA) yaitu 20 orang (67\%), responden yang berada pada pendidikan Sarjana sebanyak 10 orang (37\%) sedangkan jika dilihat dari pekerjaan, maka responden terbanyak tidak bekerja atau sebagai ibu rumah tangga (IRT) yaitu 21 orang $(70 \%)$.

Hasil pengolahan data dari hasil penelitian ditemukan bahwa sebagian responden mengalami peningkatan nilai kadar $\mathrm{Hb}$ sesudah mengkonsumsi tablet Fe. Di mana sebelum mengkonsumsi tablet $\mathrm{Fe}$ pada pengukuran I nilai $\mathrm{Hb}$ berada pada katagori rendah yaitu sebayak 19 responden atau dengan presentase 63\%. Sedangkan sesudah mengkosumsi Fe pada pengukuran II nilai $\mathrm{Hb}$ berada pada katagori tinggi sebanyak 23 orang atau dengan presentase $77 \%$. Berdasarkan hasil pemeriksaan $\mathrm{Hb}$, nilai $\mathrm{Hb}$ yang termasuk dalam katagori rendah pada usia kehamilan trimester III adalah sebagai berikut : bila $\mathrm{x}$ $>11$ dan rendah bila $\mathrm{x}<11$ (Eniyati dan Devi, 2017). Hasil pengkatagorian tersebut dapat dilihat pada tabel 1 . 
Tabel 1. Distribusi Frekuensi Responden Berdasarkan Pemeriksaan Hb Tahap I dan II

\begin{tabular}{clcc}
\hline No & \multicolumn{1}{c}{ Variabel } & f & $\mathbf{\%}$ \\
\hline 1 & Pemeriksaan Hb sebelum konsumsi Fe & & \\
& a. Kadar Hb rendah & 19 & 63 \\
& b. Kadar Hb tinggi & 11 & 37 \\
\hline 2 & Pemeriksaan Hb sewaktu konsumsi Fe & & \\
& a. Kadar Hb rendah & 7 & 23 \\
& b. Kadar Hb tinggi & 23 & 77 \\
\hline
\end{tabular}

Dari hasil analisis diketahui bahwa nilai $\mathrm{Hb}$ pemeriksaan pada tahap I pada ibu hamil di Klinik Kusumahati Jaten, Karanganyar Tahun 2018 berada dalam kategori rendah yaitu sebanyak 19 responden dengan persentase $63 \%$. Zat besi adalah mineral yang dibutuhkan guna membentuk sel darah merah. Mineral ini juga berfungsi sebagai komponen untuk membentuk mioglobin (protein yang membawa oksigen ke otot). Salah satu unsur terpenting di dalam proses pembentukan sel darah merah (eritrosit) adalah zat besi (Ferrum). Zat besi dapat diperoleh dari makanan. Kekurangan zat besi dalam menu makanan sehari-hari dapat menimbulkan defisiensi zat besi (Rochimah, 2013). Pada keadaan kehamilan kebutuhan akan oksigen $\left(\mathrm{O}_{2}\right)$ akan jauh lebih tinggi sehingga meningkatan produksi eritropoetin di dalam tubuh (Fanny, et al, 2012). Akibatnya volume plasma bertambah dan sel darah merah meningkat. Akan tetapi meningkatnya volume plasma darah akan terjadi dalam proporsi yang jauh lebih besar apabila dibandingkan dengan meningkatnya eritrosit (sel darah merah) sehingga akan terjadi penurunan konsentrasi hemoglobin $(\mathrm{Hb})$ yang disebabkan oleh faktor hemodilusi (Wahyuni dan Laniyatun, 2013). Konsentrasi hemoglobin normal pada wanita hamil berbeda dengan wanita yang tidak sedang hamil. Hal ini disebabkan karena pada kehamilan terjadi proses hemodilusi atau pengenceran darah, yaitu peningkatan volume plasma dalam proporsi yang lebih besar jika dibandingkan dengan peningkatan eritrosit. Hemodilusi berfungsi agar suplai darah untuk pembesaran uterus terpenuhi, melindungi ibu dan janin dari efek negatif kehilangan darah saat proses melahirkan (Eniyati dan Devi R, 2017). Selain hal tersebut, faktor yang menyebabkan rendahnya nilai $\mathrm{Hb}$ pada ibu hamil adalah penyerapan zat besi. Menurut Wahyuningsih (2016) ada beberapa faktor yang mempengaruhi penyerapan zat besi adalah tannin. Tanin merupakan polifenol yang terdapat di dalam teh, kopi dan beberapa jenis sayuran dan buah yang menghambat penyerapan zat besi. Kalsium dosis tinggi dapat menghambat penyerapan zat besi namun mekanismenya belum pasti. Hasil analisis untuk pengukuran tahap II pada ibu hamil di Klinik Kusumahati Jaten, Karanganyar Tahun 2018 termasuk dalam kategori Tinggi yaitu sebanyak 23 responden dengan persentase $77 \%$. Peningkatan jumlah $\mathrm{Hb}$ pada pemeriksaan tahap II disebabkan karena ibu hamil telah mengkonsumsi tablet zat besi. Selain itu responden patuh dalam mengkonsumsi tablet tersebut. Hal ini disebabkan karena dipengaruhi oleh beberapa hal yaitu umur 
responden yang umumnya berada pada umur di atas 20 tahun.

Hasil penelitian tersebut salah satu faktor yang mempengaruhi adanya hubungan antara konsumsi tablet zat besi dengan peningkatan haemoglobin adalah tingkat pendidikan. Dari hasil uji statistik didapatkan $67 \%$ responden berpendidikan menengah ke atas. Dengan tingginya persentase ibu yang berpendidikan menengah hal ini dapat mempengaruhi ibu dalam memperoleh pengetahuan tentang pentingnya konsumsi zat besi (Fe). Semakin tinggi pendidikan seseorang maka lebih mudah dalam menyerap informasi dari berbagai sumber informasi. Hal ini sesuai dengan teori yang dikemukakan oleh Wahyuningsih (2016) bahwa pendidikan juga mempengaruhi proses belajar. Semakin tinggi pendidikan seseorang semakin mudah orang tersebut menerima informasi. Seseorang dengan pendidikan tinggi cenderung lebih mampu dalam menyerap informasi dengan baik dari berbagai sumber informasi. Berdasarkan hasil penelitian yang dilakukan oleh Saragih (2010), ibu hamil yang berpendidikan tinggi mempunyai peluang 3,7 kali lebih besar untuk memperoleh pengetahuan yang lebih baik dibandingkan dengan ibu hamil yang mempunyai pendidikan dasar dan menengah. Hasil penelitian ini didukung oleh penelitian Mulyani, dkk (2017) yang menyatakan bahwa terdapat hubungan pendidikan dengan tingkat pengetahuan dan kepatuhan ibu dalam mengkonsumsi zat besi. Selain itu penelitian Intarti dan Lina (2017) menyatakan bahwa ada hubungan yang signifikan antara pendidikan dengan pengetahuan dan status anemia karena dengan pendidikan ibu yang rendah, diasumsikan pengetahuan tentang gizi juga rendah sehingga berpeluang untuk terjadinya anemia dan sebaliknya jika ibu hamil berpendidikan tinggi, maka kemungkinan besar pengetahuannya tentang gizi juga tinggi sehingga diasumsikan kecil peluangnya untuk terjadi anemia. Pengetahuan yang tinggi tentang gizi terutama tentang anemia pada ibu hamil, maka akan berperilaku yang baik dalam mengkonsumsi tablet zat besi (Fe). Hal ini sesuai dengan penelitian yang dilakukan oleh Ungsianik dan Fandiar (2013) yang menyatakan bahwa terdapat hubungan yang kuat dan signifikan antara pengetahuan dengan perilaku ibu hamil dalam keteraturan mengkonsumsi tablet Fe. Faktor lain yang dapat mempengaruhi adalah adanya hubungan antara konsumsi zat besi dengan peningkatan hemoglobin pada ibu hamil adalah umur. Menurut Suryani dan Ina (2018), umur merupakan indikator dalam kedewasaan dalam setiap pengambilan keputusan yang mengacu pada setiap pengalaman dan sangat berpengaruh terhadap pengetahuan ibu hamil tentang asupan zat besi selama kehamilan.

Rekomendasi dari penelitian ini adalah perlunya sosialisasi atau penyuluhan dari tenaga kesehatan atau kader kesehatan kepada ibu-ibu hamil supaya mengkonsumsi tablet zat besi sesuai dengan jumlah yang telah ditentukan agar tidak terjadi anemia giz besi pada saat hamil.

\section{KESIMPULAN}

Berdasarkan hasil penelitian dan pembahasan yang telah diuraikan maka dapat disimpulkan bahwa ada pengaruh 
antara asupan zat besi (Fe) dengan peningkatan kadar hemoglobin $(\mathrm{Hb})$ pada ibu hamil di klinik Kusumahati Jaten, Karanganyar Tahun 2018.

\section{DAFTAR PUSTAKA}

Balitbang Kemenkes RI. 2018. Riset Kesehatan Dasar; RISKESDAS. Jakarta: Balitbang Kemenkes RI.

Candra, A. 2018. "Faktor-faktor yang Memengaruhi Hasil Suplementasi Besi pada Ibu Hamil". JNH (Journal of Nutrition and Health) .6(2).

Eniyati dan Devi R. (2017). "Sikap Ibu Hamil Dalam Menghadapi Ketidaknyamanan Kehamilan Trimester I Di Puskesmas Piyungan Bantul Yogyakarta". Jurnal Kesehatan "Samodra Ilmu" Vol. 08 No. 01 Januari 2017.

Fanny, L; Mustamin, H; Dewi, T dan Kartini, St. (2012). "Pengaruh Pemberian Tablet Fe Terhadap Kadar Hemoglobin Ibu Hamil Di Puskesmas Tamamaung Tahun 2011". Media Gizi Pangan, XIII (1).

Intarti, W.D dan Lina, P. 2017. "Kontribusi Senam Ibu Hamil Trimester III Dalam Pengurangan Nyeri Pinggang Di Wilayah Ekskotatif Cilacap". Jurnal Ilmiah Kebidanan, 8 (1) 1727.

Isdiaty, F.N dan Titin, U. 2013. "Pengetahuan Tanda Bahaya Kehamilan Dan Perilaku Perawatan Kehamilan Pada Ibu Hamil Trimester Iii”. Jurnal Keperawatan Indonesia, 16 (1) 18-24.

Kartikasari, R.I dan Yusnita, A. 2018. "Pengaruh Fe-Folat Dengan Air Jeruk Terhadap Peningkatan Kadar Hemoglobin Ibu Hamil Di
BPM Siti Khalimah Lamongan”. Surya" 10 (1).

Masrizal. 2007. “Anemia Defisiensi Besi”. Jurnal Kesehatan Masyarakat, September 2007, II (1).

Mulyani, S; Ahmad, S Dan Martahiyah. 2017. "Hubungan Tingkat Pengetahuan Dan Dukungan Keluarga Terhadap Kepatuhan Ibu Hamil Mengkonsumsi Tablet Zat Besi”. JMJ, 5 (2) $151-163$.

Notoatmodjo, S. 2002. Metodologi Penelitian Kesehatan. Jakarta: Rineka Cipta.

Rizki, F; Nur, I.L dan Hirowati, A. 2017. "Hubungan Suplementasi Tablet Fe dengan Kadar Hemoglobin pada Ibu Hamil Trimester III di Puskesmas Air Dingin Kota Padang". Jurnal Kesehatan Andalas 2017 (6) 3.

Saragih, F.S. 2010. Effect of Counseling on Mother's Knowledge and Attitudes About Healthy Foods and Balanced Nutrition in Raya Brand Villages Raya District of Simalungun Regency in 2010. Thesis. University of North Sumatra (USU).

Suryani, P dan Ina, H. 2018. "Senam Hamil Dan Ketidaknyamanan Ibu Hamil Trimester Ketiga". Jurnal Bidan "Midwife Journal" 5 (1).

Ungsianik, T Dan Fandiar, N.I. 2013. "Pengetahuan Tanda Bahaya Kehamilan Dan Perilaku Perawatan Kehamilan Pada Ibu Hamil Trimester III". Jurnal Keperawatan Indonesia, 16 (1) 18-24.

Wahyuni dan Laniyatun, N. (2013). "Manfaat Senam Hamil Untuk Meningkatkan Durasi Tidur Ibu Hamil". Jurnal Kesehatan Masyarakat KEMAS, 8 (2) 145-152.

Wahyuningsih, E. 2016. "Peningkatan Kadar Hemoglobin Pada Ibu Hamil Melalui Konsumsi Tablet Multiple Micro Nutrient di Puskesmas Kalikotes Klaten". ISSN 24079189 The 3rd Universty Stikes Muhammadyah Klaten Research Colloquium 2016. 